Welfare policy in the presence of unionised labour and internationally mobile firms

Silvia Rocha-Akis

Ronnie Schöb

School of Business \& Economics

Discussion Paper

Economics

$2009 / 14$

978-3-941240-08-7 


\title{
Welfare policy in the presence of unionised labour and internationally mobile firms*
}

\author{
Silvia Rocha-Akis ${ }^{\dagger} \quad$ Ronnie Schöb ${ }^{\ddagger}$
}

August 17, 2009

\begin{abstract}
In oligopolistic industries that are unionised and may be affected by offshoring, falling offshoring costs have a moderating effect on trade unions. They will accept lower sector wages in order to discourage mobile firms from leaving the country. Since such wages are independent of the workers' domestic outside opportunities, wage moderation - induced by deeper economic integration - creates leeway for the government to engage in redistributive policies even if this improves the workers' domestic outside options. Only if the latter become sufficiently attractive will redistribution induce some offshoring, and it is only at that level that further economic integration will lead to both wage moderation and offshoring activities. Therefore, our analysis suggests that rather than provoking a downsizing of the welfare state, offshoring defines an upper limit for the generosity of the welfare state below which redistribution becomes less instead of more distortive.
\end{abstract}

Keywords: offshoring, import competition, wage bargaining, oligopoly, redistribution JEL classification: F16, H30, H50, J30, J50, L10

${ }^{*}$ We thank Ana B. Ania, Andreas Knabe, the editor Espen Moen and two anonymous referees for very helpful comments on an earlier version of this paper. Part of this work was done while Rocha-Akis was working at the Oesterreichische Nationalbank and when visiting the FU Berlin.

$\dagger$ Department of Economics, Vienna University of Economics and Business, Nordbergstr. 15, 1090 Vienna, Austria. Tel: +43 6768213 5855, Fax:+43-1-31336/905800, Email:silvia.rocha@wu-wien.ac.at

${ }^{\ddagger}$ School of Business \& Economics, Freie Universität Berlin, Boltzmannstr. 20, D-14195 Berlin, Germany. Email: ronnie.schoeb@fu-berlin.de 


\section{Introduction}

In recent years, industrialised countries have seen considerable outward relocations of production. Not surprisingly, due to its direct impact on employment, offshoring has become an increasingly important topic in public debates, particularly in countries characterised by high unemployment and low job creation.

In line with the growing trend towards foreign direct investment (FDI), an impressive amount of literature on the determinants and the welfare implications of inward FDI has emerged. Far less attention has been devoted to the determinants and consequences of outward FDI, which - in the presence of regulated labour markets and state-provided welfare arrangements - are increasingly prone to generating conflict between labour unions, employers' organisations and policy-makers.

In general, from the perspective of old industrialised countries, the importance of outward relocations of production may have grown due to several novel developments, such as (i) an increasing supply of low-wage, highly skilled labour, (ii) the reduction in the costs of global communication due to advances in financial, information and communication technologies, (iii) the improved tradability of services which can be delivered electronically and do not require face-to-face contact, and (iv) financial liberalisation and the rise in capital mobility. It is a widely established fact that one of the key determinants of location choices for production is the cost of labour (see e.g. Barrell and Pain, 1996; Hatzius, 1998, 2000; Pennings and Sleuwaegen, 2000, 2006 for empirical evidence). Labour unions are frequently blamed for strengthening the trend towards moving production to lower-wage countries. ${ }^{1}$ In many European countries, trade unions succeed in keeping wage rates above the market-clearing level, thus raising domestic wage costs and strengthening the tendency towards offshore production. This effect may be exaggerated by government interventions including high tax rates on labour income and high social insurance contributions combined with generous unemployment benefits, because these policy measures increase wage pressure in wage negotiations between trade unions and firms (see e.g. Lockwood, 1990; Goerke, 1999; Daveri and Tabellini, 2000; Nickell, 2003; Koskela and Schöb, 2002) and, may consequently further increase the incentives for firms to move production offshore. Notwithstanding the impres-

\footnotetext{
${ }^{1}$ Although the number of union members in the OECD has declined over the last two decades, the share of employees whose remuneration and working conditions are directly or indirectly determined by collective bargaining is still considerable. In the EU, this share ranged from $30 \%$ in the UK to $68 \%$ in Germany, $90 \%$ in Belgium, Finland, France and Sweden, and 95\% in Austria in the year 2000 (OECD, 2004).
} 
sive growth in labour taxation and social insurance contributions in most OECD countries, ${ }^{2}$ the economic literature on fiscal policy and FDI has almost exclusively focused on capital taxation and lump sum policies.

Our investigation builds on two strands of literature, namely the literature on FDI and the literature on non-competitive labour markets and taxation. The question we address is how, in the presence of a unionised labour force and internationally mobile and immobile oligopolistic firms, the redistributive policies of the welfare state affect domestic employment in industries which are potentially susceptible to offshoring. This involves exploring how firms and labour unions interact and respond to changes in the social security system in the face of global competition.

The main features of our model are as follows: We consider an industry consisting of two profit-maximising firms that produce a homogeneous good using labour as the only factor of production. The workers in the industry constitute only a small fraction of the overall labour force. Accordingly, welfare policy is exogenous from this industry's point of view. Wages are negotiated by a labour union and domestically located firms. The government imposes a tax on wages and uses the revenue to finance unemployment insurance payments and other public goods. Within the sector, not all companies are equally able to take advantage of cheaper technology by means of offshoring. Specifically, we assume that both firms differ in terms of mobility, as only one of them, a multi-national enterprise (MNE), may choose to relocate its production facility to a foreign country from which it can serve the domestic market.

The main result is as follows. When offshoring becomes attractive for mobile firms, the trade union is tamed. It will moderate sector wages in such a way as to discourage the mobile firm from leaving the country. In fact, the negotiated wage rate becomes independent of the workers' domestic outside opportunities and as such creates leeway for the government to engage in redistributive policies. Thus, in the presence of firm mobility there remains scope for substantial redistribution without the threat of losing production. Only if workers' domestic outside opportunities are sufficiently attractive, redistribution induces some offshoring and it is only at that level that further economic integration will lead to both wage moderation and offshoring activities.

The paper is organised as follows: Section 2 links this work to related literature. Section

\footnotetext{
${ }^{2}$ See Joumard (2001). In the EU-25, labour tax revenues contribute to around half of total tax receipts and finance most social welfare programmes (European Commission, 2006).
} 
3 describes our model of a single-sector unionised duopoly. In section 4, we then look at the alternative interactions between the union and the firms during wage negotiations. The union's stance with regard to offshoring serves to determine the equilibrium wage depending on the workers' outside option. The impact of increased economic integration on domestic wage negotiations is then analysed in section 5 . Section 6 endogenises the outside option of workers and shows how wage negotiations and offshoring are affected by the government's welfare policy. Section 7 concludes the paper.

\section{Related literature}

Most theoretical contributions on the welfare implications of (inward or outward) FDI in the presence of unionised labour markets focus on the conflict of interest between unions and firms without considering public policy. ${ }^{3}$ Exceptions include Bughin and Vannini (1995), Leahy and Montagna (2000), and Skaksen (2005), who quantify the potential welfare gain from inward FDI as a measure for a lump sum subsidy. Brander and Spencer (1988) and Mezzetti and Dinopoulos (1991), on the other hand, examine the effects of trade policy. Another stream of literature analyses the incentives of governments to attract inward FDI by means of capital taxes. As noted by Desai et al. (2004), studies on the effects of tax policy on the location of FDI focus almost exclusively on corporate income taxes. ${ }^{4}$ The role of distortionary labour taxation on the cost side of mobile firms (or production) and its welfare implications has been analysed by Aronsson and Sjögren (2004), Rocha-Akis (2007), Koskela and Schöb (2009), Koskela and Poutvaara (2009), and Keuschnigg and Ribi (2009). Anderson (2003) has shed light on the link between firm mobility and the implementation of welfare programmes but focuses on changes in the degree of centralisation of the labour market and their implications for the costs of maintaining publicly financed welfare systems. In a multi-country model, Aronsson and Sjögren (2004) focus on optimal labour taxation and policy coordination when firms are mobile and labour is unionised. In their framework, competitive firms which may relocate to another jurisdiction use the potential profit obtainable abroad as a threat during wage negotiations. The assumptions that all firms are identical and that redistributive policies are adjusted in such a way as to maximise welfare

\footnotetext{
${ }^{3}$ E.g. Zhao (1995, 1998), Naylor and Santoni (1998), Skaksen and Sørensen (2001), Lommerud et al. (2003), Munch (2003), Skaksen (2004), Eckel and Egger (2009).

${ }^{4}$ Examples which consider this link in the presence of unionised labour markets include Boadway et al. (2002), and Haufler and Mittermaier (2008).
} 
imply that relocation never takes place in equilibrium, as national governments coordinate optimally by reducing unemployment benefits and thus also wages.

Rocha-Akis (2007) analyses labour taxation and transfer policy in situations where imperfectly competitive firms may relocate abroad and the domestic labour market is unionised, showing how the specification of the government's objective determines the equilibrium outcome. One result is that a government that attaches sufficient weight to domestic consumer and producer surplus may find it optimal to set a high tax-and-transfer schedule even if it pushes part of production abroad, thus reducing domestic output and employment. This is because such a policy enforces lower wage demands from unions and therefore enhances the profits of domestically located producers as well as total output.

Koskela and Schöb (2009) investigate the implications of alternative labour tax reforms for domestic employment when identical and perfectly competitive firms face a unionised workforce that can be partly substituted by foreign labour in outsourcing arrangements. Their main findings are that a decrease in outsourcing costs may bring about a wage moderation effect that dominates the labour substitution effect, thereby enhancing domestic employment. Moreover, the negative employment consequences of higher labour taxes, higher unemployment benefits and lower tax exemption rates are shown to be magnified in the presence of outsourcing.

Using a two-country setup with perfectly competitive firms, Keuschnigg and Ribi (2009) analyse how outsourcing affects welfare policies in high-wage economies. The model allows for high and low-skilled workers, with only the latter running the risk of unemployment due to outsourcing. The labour market for low-skilled workers is described within a matching framework, while the wage rate of high-skilled workers is fixed. It turns out that an increase in the unemployment benefits increases the wages of low-skilled workers and leads to an unambiguous marginal increase in aggregate outsourcing activity. On the other hand, more redistribution by means of a higher tax used to finance a tax cut for low-skilled workers contributes to a decrease in low-skilled workers' gross wages, while increasing their net wages and thereby stimulating labour market participation. The paper concludes that governments should expand the welfare state to provide better insurance.

Several empirical studies on the effects of outward relocations on employment and wages have been conducted. In this context it should be noted that comprehensive measures of production relocations are hardly available. This may reflect a serious data collection prob- 
lem since shifts of production are at best concealed within the broader data categories of FDI and imports. Based on intermediate good import data as a measure of cross-border sourcing of intermediate inputs, this literature is generally inconclusive regarding the net effects on domestic labour demand. A majority of studies, however, find that international outsourcing (also referred to as offshore outsourcing) seeks to reduce costs and tends to drive down wages or, in the presence of wage rigidities, decrease employment among low-skilled workers in the country where production was initially carried out. Moreover, low-skilled workers in low-wage countries are generally believed to be complements to high-skilled workers in high-wage countries. ${ }^{5}$ Empirical contributions examining the potential link between welfare policies and production relocations are rare. Using firm-level data, a recent study by Delbecque et al. (2008) analyses whether and how various dimensions of labour market regulation affect firms' expansion strategies in foreign countries. The results indicate that among other institutional arrangements stringent employment protection laws, a generous unemployment benefit system, strong minimum wage constraints, and powerful trade unions significantly reduce the propensity of firms to locate in a country.

\section{Firm behaviour}

Our model extends Bughin and Vannini's (1995) unionised oligopoly model of FDI by incorporating a redistributive welfare state. In this context, we primarily focus on a single industry consisting of a duopoly that produces a homogeneous good. The duopolists face a trade union which operates throughout the industry in the home country. In the background there is a second country, referred to as the foreign country, which is considered exogenous in our model. The two firms differ in terms of mobility: Firm $d$ is assumed to be immobile, whereas firm $f$ is a branch plant of an MNE which has the option of moving production abroad. The domestic government taxes labour income and provides benefits for unemployed workers. The domestic welfare policy, which is exogenous from the industry's viewpoint, has an impact on the labour union's bargaining strategy as it affects the workers' outside option, which in turn influences firms' investment and cross-border location decisions and thus the level of domestic production and employment.

\footnotetext{
${ }^{5}$ See for example Feenstra and Hanson (1999), Egger, Pfaffermayr and Wolfmayr (2001), Egger and Egger (2003), Ekholm and Hakkala (2006) and Falk and Wolfmayr (2005). Making use of plant-level data for the Irish Electronics sector, Görg and Hanley (2005) find that offshore outsourcing significantly decreases labour demand in the short-run. Crinò (2009) provides an extensive overview of the empirical literature.
} 
Two different scenarios are possible: In the first scenario, both firms produce domestically. In the second scenario, the mobile firm has relocated abroad. Whereas in the former case both firms are subject to wage negotiations with a domestic labour union, in the latter scenario only the immobile firm has to pay the negotiated wage, while the mobile firm faces exogenously determined foreign labour input costs. Our aim is to analyse the extent to which redistributive policies affect the mobile firm's decision to move abroad.

\begin{tabular}{|c|c|c|c|}
\hline $1^{\text {st }}$ stage & $2^{\text {nd }}$ stage & $3^{\text {rd }}$ stage & $4^{\text {th }}$ stage \\
\hline Tax policy & Wage bargaining & Location decision & $\begin{array}{c}\text { Output } \\
\text { and employment }\end{array}$ \\
\hline
\end{tabular}

Figure 1: Timing of events.

Figure 1 illustrates the sequence of decisions over time. The sector takes the tax policy decisions made in stage 1 as given when wage negotiations take place. Given the negotiated wage rate, the MNE decides on its production location in stage 3. Finally, each firm chooses its optimal output and employment level. Since the location decision as well as the output and employment decisions are anticipated in the wage negotiations, we solve the problem recursively by means of backwards induction.

\subsection{Output and employment}

Both firms produce a homogeneous good and face a linear inverse demand function of the form $p(Q)=\alpha-\beta Q$, where $\alpha, \beta>0, p$ is the output price, and $Q=q_{d}+q_{f}$ denotes the sum of individual quantities produced by firms $d$ and $f$. Labour is the only factor of production. Each firm $i=d, f$ has access to the same linear technology, which is normalised in such a way that one unit of output is produced with one unit of labour. Thus, $q_{i}$ represents both output and labour input. Labour is remunerated at a gross wage rate of $\omega_{i}$. Consequently, the profit functions are $\pi_{i}=\left[p(Q)-\omega_{i}\right] q_{i}$, where $0<\omega_{i}<\alpha$ ensures positive equilibrium production. In stage 4 , each firm $i$ takes the wage outcome $\left(\omega_{d}, \omega_{f}\right)$ resulting from wage bargaining as given and strategically chooses its profit-maximising employment and output level $q_{i}$. The resulting equilibrium output of firm $i$ is a function of both firms' labour costs and given by

$$
q_{i}\left(\omega_{i}, \omega_{j}\right)=\frac{\alpha-2 \omega_{i}+\omega_{j}}{3 \beta}, \quad i=d, f, i \neq j
$$


reflecting the fact that the optimal choice of output by firm $i$ in strategic quantity-setting depends on the output produced in the competing firm $j$. Substituting (1) into the profit function, we can express profits as follows: ${ }^{6}$

$$
\pi_{i}\left(\omega_{i}, \omega_{j}\right)=\beta\left[q_{i}\left(\omega_{i}, \omega_{j}\right)\right]^{2}, \quad i=d, f
$$

\subsection{The location decision}

If the internationally mobile firm decides not to offshore, it faces the same domestic industry wage as its immobile competitor. Otherwise, it faces the given foreign wage $\bar{\omega}_{f}$ and the fixed relocation cost $K$. The latter may capture factors such as putting infrastructure in place, laying off employees at home, hiring and training new workers, paying for legal and consulting fees, and the like. ${ }^{7}$ The firm chooses the location where the profit is highest. Therefore, firm $f$ relocates if $\pi_{f}^{r}\left(\bar{\omega}_{f}, \omega_{d}^{r}\right)-K \geq \pi_{f}^{n}\left(\omega^{n}, \omega^{n}\right)$. Throughout the analysis, the superscripts $r$ and $n$ refer to variables in the regime with and without outward relocation, respectively. Since the profits from domestic (foreign) production decrease (increase) with the domestic wage, there exists an indifference wage $\widetilde{\omega}\left(\bar{\omega}_{f}, K\right)$ that renders the mobile firm indifferent to offshoring versus not offshoring, i.e. $\pi_{f}^{r}\left(\bar{\omega}_{f}, \widetilde{\omega}\right)-K=\pi_{f}^{n}(\widetilde{\omega}, \widetilde{\omega})$. Using (1) and (2), this indifference wage is given by

$$
\widetilde{\omega}\left(\bar{\omega}_{f}, K\right):=\bar{\omega}_{f}+\frac{9 \beta}{4\left(\alpha-\bar{\omega}_{f}\right)} K
$$

Should the domestic wage exceed $\widetilde{\omega}\left(\bar{\omega}_{f}, K\right)$, offshoring will take place; otherwise the mobile firm will prefer to produce domestically. The indifference wage increases in $\bar{\omega}_{f}$ and $K$. Intuitively, the higher the costs associated with offshoring, the higher the domestic wage can be without triggering the outward relocation of production.

\section{Wage bargaining in partial equilibrium}

The sector-specific labour force is normalised to unity and represented by a sector-specific trade union. We assume "right-to-manage" wage formation, that is, the firms and the union

\footnotetext{
${ }^{6}$ This is a standard result for the Cournot oligopoly game with linear demand and constant marginal costs. In this case, each firms' profit is proportional to the square of its output; see e.g. Jehle and Reny (2000, p. 162).

${ }^{7}$ Görg (2002) and Dewit et al. (2003) empirically examine the extent to which a high level of employment protection discourages outflow FDI.
} 
bargain over the wage rate, leaving each firm $i$ with the right to subsequently determine the output and employment levels. Moreover, we abstract from workers' choices regarding the allocation of time between work and leisure, and assume that the individual labour supply is inelastic. Workers employed at firm $i$ earn a net-of-tax wage income $\omega_{i}(1-\tau)$ where $\tau$ is the income tax rate. Workers who do not find employment in this industry become unemployed with a probability equal to the domestic aggregate unemployment rate $u$, in which case they are entitled to receive some gross unemployment benefit payments $b$, or they find employment in one of the other domestic sectors with a probability of $1-u$ where they earn the expected gross wage $\bar{\omega}$. Thus the individual's gross outside option is given by

$$
\gamma=(1-u) \bar{\omega}+u b
$$

The unemployment benefit payments $b$ may be proportional to the average wage or fixed in order to guarantee a minimum subsistence level of welfare.

In the sections that follow we derive the negotiated wage rate in this sector for a given outside option by first analysing the case where both firms produce domestically (section 4.1) and then addressing the scenario where the MNE has moved its plant offshore (section 4.2). This information is used to analyse the union's stance towards offshoring and to identify the scope for wage moderation in section 4.3. Throughout sections 4 and 5 , we determine the wage within a sector, given the behaviour in all other sectors. Finally, we endogenise the outside option and determine the general equilibrium in section 6 .

\subsection{Wage bargaining without relocation}

The objective of the union is to maximise the following union rent:

$$
\theta_{n}=\sum_{i=1}^{2}\left(\omega_{i}-\gamma\right)(1-\tau) q_{i}\left(\omega_{i}, \omega_{j}\right), \quad i, j=d, f
$$

where $\omega_{i}>\gamma$ ensures that workers are willing to work in the industry. Notice that the union has two opposing goals: On the one hand, it aims to negotiate as high a wage rate in excess of the gross outside income as possible; on the other hand, it strives to achieve as high a level of employment as possible. The objective of each firm is to maximise its profit. It is standard practice in the literature on union-firm bargaining to allow for exogenous relative bargaining power during wage contract negotiations. This is captured by the Nash 
bargaining product

$$
\Omega_{n}\left(\omega_{i}, \omega_{j}\right)=\theta_{n}^{\delta}\left(\sum_{i=1}^{2} \pi_{i}\left(\omega_{i}, \omega_{j}\right)\right)^{1-\delta}, \quad i, j=d, f
$$

where $\delta \in[0,1]$ and $1-\delta$ denote the relative bargaining power of the union and the firms, respectively. This formulation reflects the fact that both firms are represented by a joint bargaining entity, for example an employers' association, implying that the firms' bargaining power is identical. Wage bargaining is thus realised so as to maximise the industry profits, whereas output is determined in such a way as to maximise the individual firm's profits. In effect, firms compete in the output market, but they bargain jointly for wages. ${ }^{8}$

If the wage negotiations break down, each party ends up receiving the fallback payoff. In that case, workers would exit the industry and firms would cease production. As they are chosen by the government at a prior stage, the levels of the policy variables $\tau$ and $b$ are treated as exogenous by both the firms and the union.

Note that we are confronted with a symmetric case in the sense that both the good produced and the labour force are homogeneous. Consequently, the union treats all workers equally, thus the equilibrium wage arising from wage bargaining will be identical for all employed workers regardless of the particular firm at which they are employed. Furthermore, according to equation (1) the output level is also symmetric, amounting to

$$
q(\omega)=\frac{\alpha-\omega}{3 \beta}
$$

where $\omega=\omega_{d}=\omega_{f}$. As a consequence, the outcome of the bargain will be the wage rate that maximises the following Nash product

$$
\Omega_{n}(\omega)=[(\omega-\gamma)(1-\tau) 2 q(\omega)]^{\delta}\left[2 \beta(q(\omega))^{2}\right]^{1-\delta}, \quad i, j=d, f
$$

${ }^{8}$ Zhao (1995) is among the few papers that model asymmetric union-firm bargaining. In his one-way FDI setting, one union bargains with two firms, of which only one is able to produce abroad in the case of disagreement. Both firms serve the domestic and the foreign markets. The union's fallback is the exogenous competitive wage which is identical in both countries. The model is more general in that each of the three bargaining parties is allowed to have a different level of relative negotiation power. However, in order for the problem to remain tractable, it is assumed that bargaining takes place simultaneously and independently in both countries, and that renegotiation is not possible. Specifically, during wage negotiations in one country, firms' output and employment decisions in the other country are taken to be fixed. This is in sharp contrast to our approach, which is to model the extreme cases of joint bargaining (no relocation regime) and asymmetric bargaining (relocation regime, discussed in the next section). The asymmetric bargaining, which ultimately determines the fallback profit of the mobile firm, allows us to consider explicitly how the domestic firm's output depends on the competitor's output, which in turn depends on both countries' wage rates. Hence, the competitor's output decision is endogenous in wage negotiations. 
From the first-order condition, we can derive the unconstrained negotiated wage: ${ }^{9}$

$$
\omega^{n}(\delta, \gamma)=\frac{\delta}{2} \alpha+\left(1-\frac{\delta}{2}\right) \gamma
$$

with $0 \leq \gamma<\alpha$. One can easily verify that the second-order condition for a maximum is fulfilled. From (1) we can determine the equilibrium output and employment level:

$$
q\left(\omega^{n}(\delta, \gamma)\right)=q^{n}(\delta, \gamma)=\frac{2-\delta}{6 \beta}(\alpha-\gamma)
$$

Expression (9) shows that the wage is a weighted average of the buyers' maximum willingness to pay and the workers' expected outside income, $\gamma$, with the weights determined by the union's relative power in negotiations. The stronger the union, the more weight is attributed to $\alpha$, thus contributing to a higher wage. From (4) it is clear that the wage increases with $\bar{\omega}$ and $b$, as these variables raise the expected outside income of union members and therefore improve their bargaining position. A higher rate of domestic unemployment, on the other hand, lowers the workers' expected outside prospects, thereby weakening the negotiation position of the union and dampening the wage, i.e. $\partial \gamma / \partial u=-(\bar{\omega}-b)<0$.

\subsection{Wage bargaining with relocation}

If the MNE relocates its plant to the foreign country, both firms will choose their output levels according to equation (1), where the wage rate paid by the offshoring firm, $\bar{\omega}_{f} \in(0, \alpha)$, is exogenous. Both the domestic union and the domestic firm anticipate the asymmetric game in the product market and bargain over the domestic wage rate. The Nash bargaining product is given by

$$
\Omega_{r}\left(\omega_{d}, \bar{\omega}_{f}\right)=\theta_{r}^{\delta}\left[\pi_{d}^{r}\left(\omega_{d}, \bar{\omega}_{f}\right)\right]^{1-\delta}
$$

where

$$
\theta_{r}=\left(\omega_{d}-\gamma\right)(1-\tau) q_{d}\left(\omega_{d}, \bar{\omega}_{f}\right)
$$

\footnotetext{
${ }^{9}$ See appendix A.1 for a derivation.
} 
represents the union rent. Solving for the maximisation problem, we obtain the following equilibrium gross domestic wage in the relocation regime: ${ }^{10}$

$$
\begin{aligned}
\omega_{d}^{r}\left(\delta, \gamma, \bar{\omega}_{f}\right) & =\frac{\delta}{4}\left(\alpha+\bar{\omega}_{f}\right)+\left(1-\frac{\delta}{2}\right) \gamma \\
& =\omega^{n}(\delta, \gamma)-\frac{\delta}{4}\left(\alpha-\bar{\omega}_{f}\right)
\end{aligned}
$$

where the second-order condition for a maximum is fulfilled. Given $\delta, \gamma$, and $\bar{\omega}_{f}$, a comparison of expressions (9) and (13) shows that the domestic wage is lower when the mobile firm has moved abroad. By substituting (13) into (1), we obtain the equilibrium domestic production and employment level:

$$
\begin{aligned}
q_{d}^{r}\left(\delta, \gamma, \bar{\omega}_{f}\right) & =\frac{2-\delta}{3 \beta}\left(\frac{\alpha+\bar{\omega}_{f}}{2}-\gamma\right) \\
& =2 q^{n}(\delta, \gamma)-\frac{2-\delta}{6 \beta}\left(\alpha-\bar{\omega}_{f}\right)
\end{aligned}
$$

In order to rule out a situation where one of the firms becomes a monopolist, equation (1) requires that $2 \bar{\omega}_{f}-\alpha \leq \omega_{d}^{r}\left(\delta, \gamma, \bar{\omega}_{f}\right) \leq\left(\alpha+\bar{\omega}_{f}\right) / 2$, a condition which essentially guarantees that the domestic wage does not diverge too far with respect to its foreign counterpart. Whereas the former constraint is always fulfilled if $\bar{\omega}_{f}<\alpha / 2$, the latter constraint is implied by the requirement of a positive union rent, which in turn implies that $\gamma \leq \gamma_{\max }\left(\bar{\omega}_{f}\right):=\left(\alpha+\bar{\omega}_{f}\right) / 2$. Note that in both scenarios - with and without relocation of the MNE - the union rent increases with the domestic wage. ${ }^{11}$ Since the firms produce the same good, it is not surprising that for any given level of $\gamma$, offshoring results in a lower level of total domestic industry employment. This is easily shown by a comparison of expressions (10) and (14). Thus, the union is aware that beyond the negative incremental employment effect associated with an incremental increase in labour costs, the wage-employment tradeoff may be critically aggravated in the presence of international firm mobility, as a higher wage may translate into the closure of an entire production facility, thus generating non-linear effects on domestic employment and wages. It is precisely this rationale that motivates our considerations in

\footnotetext{
${ }^{10}$ See appendix A.2 for details.

${ }^{11}$ This is revealed by partially differentiating the union rent given by (5) with respect to $\omega^{n}$, that is, $\frac{\partial \theta_{n}}{\partial \omega^{n}}=\frac{2(1-\tau)}{3 \beta}\left[\alpha-2 \omega^{n}+\gamma\right]$. Setting $\omega^{n}=\omega^{n}(\delta, \gamma)$ as specified in (9), we can express the term in square brackets as $(1-\delta)(\alpha-\gamma)>0$. Therefore, $\frac{\partial \theta_{n}}{\partial \omega^{n}}>0$. Similarly, partially differentiating (12) with respect to the domestic negotiated wage results in $\frac{\partial \theta_{r}}{\partial \omega_{d}}=\frac{(1-\tau)}{3 \beta}\left[\alpha-4 \omega_{d}+2 \gamma \bar{\omega}_{f}\right]$. Using expression (13), the term in brackets becomes $\left(\alpha+\bar{\omega}_{f}\right)(1-\delta)+2[2+\gamma(1+\delta)]>0$.
} 
the next section.

\subsection{The union's attitude towards offshoring and the role of the workers' outside option}

So far, we have identified the unconstrained negotiated wage for the two scenarios. Obviously, if the negotiated wage as determined by (9) is below the indifference wage, i.e. $\omega^{n}(\delta, \gamma)<\widetilde{\omega}\left(\bar{\omega}_{f}, K\right)$, both firms will produce domestically. This case persists as long as the outside option is sufficiently low for domestic workers in the sector. More specifically, we have

$$
\omega^{n}(\delta, \gamma) \leq \widetilde{\omega}\left(\bar{\omega}_{f}, K\right) \Leftrightarrow \gamma \leq \underline{\gamma}\left(\delta, \bar{\omega}_{f}, K\right):=\frac{2}{2-\delta}\left[\bar{\omega}_{f}-\frac{\delta}{2} \alpha+\frac{9 \beta}{4\left(\alpha-\bar{\omega}_{f}\right)} K\right]
$$

If the unconstrained negotiated wage were marginally above the indifference wage, the mobile firm would move abroad, in which case the negotiated wage would correspond to $\omega_{d}^{r}\left(\delta, \gamma, \bar{\omega}_{f}\right)<\widetilde{\omega}\left(\bar{\omega}_{f}, K\right)<\omega^{n}(\delta, \gamma)$. This cannot be optimal from the viewpoint of the trade union, since fewer workers would be employed and would also receive a negotiated wage which is lower than the indifference wage. This effect arises from the marginal cost advantage the offshoring firm would have and use strategically. Since the negotiated wage increases with the workers' outside option $\gamma$, there is a level $\bar{\gamma}$ below which $\omega_{d}^{r}\left(\delta, \gamma, \bar{\omega}_{f}\right)<\widetilde{\omega}\left(\bar{\omega}_{f}, K\right)$. Hence, in the interval $\gamma \in[\underline{\gamma}, \bar{\gamma}]$ it is in the trade union's best interest not to expel the mobile producer from the domestic country, and it can do so by not raising the wage even if the outside option improves. The equilibrium union rent in the regime without offshoring is thus defined as

$$
\theta_{n}=\left\{\begin{array}{lll}
\theta_{n}^{u}(\gamma)=\left[\omega^{n}(\delta, \gamma)-\gamma\right](1-\tau) 2 q\left(\omega^{n}(\delta, \gamma)\right), & \text { if } & 0 \leq \gamma<\underline{\gamma} \\
\theta_{n}^{c}(\gamma)=\left[\widetilde{\omega}\left(\bar{\omega}_{f}, K\right)-\gamma\right](1-\tau) 2 q\left(\widetilde{\omega}^{(}\left(\bar{\omega}_{f}, K\right)\right), & \text { if } & \underline{\gamma} \leq \gamma<\widetilde{\omega}
\end{array}\right.
$$

where $\theta_{n}^{u}$ is the rent accruing to workers when the union can react to changes in $\gamma$ without triggering an outward relocation of production, while $\theta_{n}^{c}$ denotes the rent derived by the union when it adopts wage moderation (the superscripts $u$ and $c$ stand for unconstrained and constrained bargaining, respectively).

The upper part in figure 2 summarises our results so far. ${ }^{12}$ The horizontal line represents

\footnotetext{
${ }^{12}$ For the sake of notational simplicity, we omit the arguments below wherever there is no risk of confusion.
} 

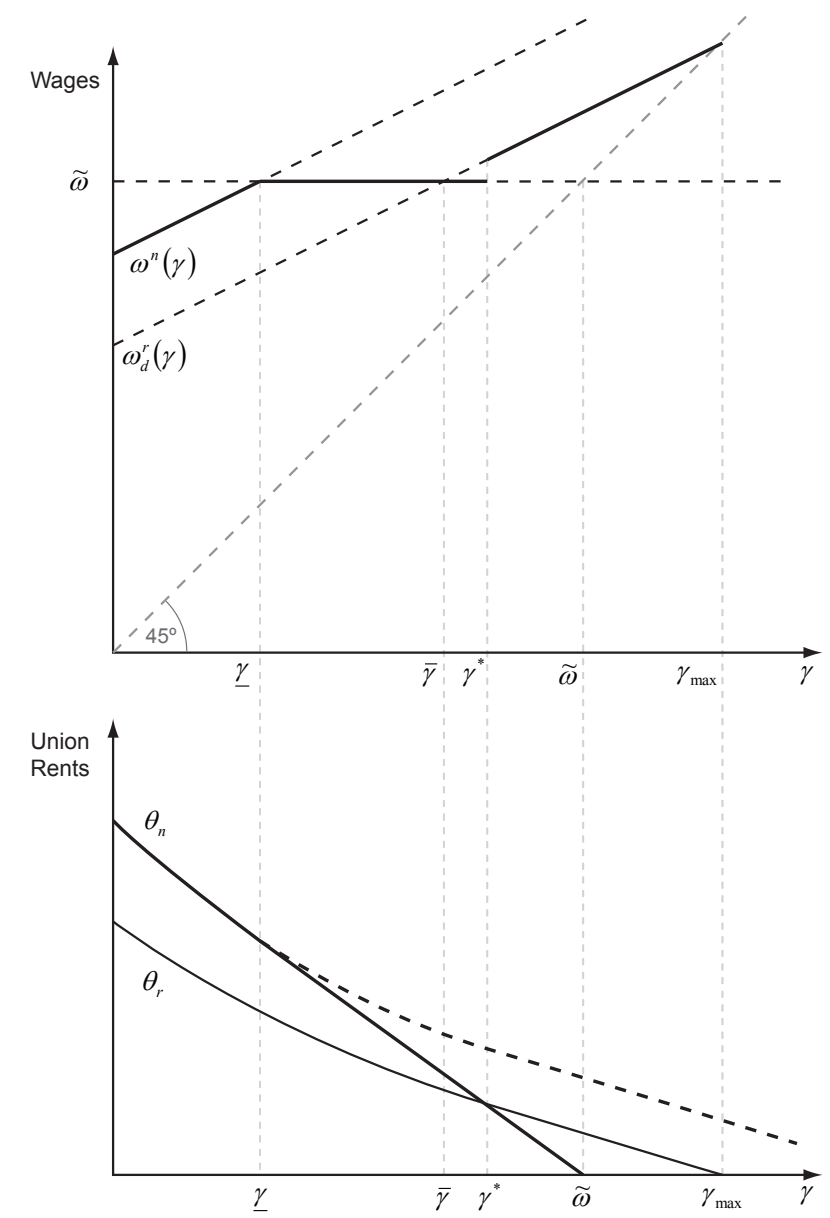

Figure 2: Equilibrium wage and union rents.

the indifference wage that is independent of the domestic workers' outside option. The $\omega^{n}(\gamma)$-curve indicates the unconstrained negotiated wage provided that both firms produce domestically, while the $\omega_{d}^{r}(\gamma)$-curve expresses the negotiated wage when the mobile firm competes from abroad. For low values of the outside option, that is, $0 \leq \gamma<\underline{\gamma}$, the domestic wage resulting from wage bargaining is below the critical level at which the possibility of relocating becomes attractive for the mobile firm. There is no threat of offshoring, and increasing outside opportunities are associated with higher wages in the sector.

For $\gamma \leq \gamma \leq \bar{\gamma}$, the union has no leeway in negotiating a wage above the critical level $\widetilde{\omega}$ because it would have to accept lower wages for fewer workers. The presence of firm mobility tames the union insofar as it is no longer able to take advantage of better outside options for its workers.

In order to see what happens when $\gamma>\bar{\gamma}$, we first look at $\gamma=\bar{\gamma}$. In this case, both firms still 
produce domestically. If the outside option is marginally above $\bar{\gamma}$, however, the negotiated wage rises above $\widetilde{\omega}$ and the mobile firm moves offshore. Nevertheless, it is still not optimal for the trade union to push for a wage rate above $\widetilde{\omega}$ because the benefit of a marginally higher wage would come at the cost of losing the jobs provided by the mobile firm. This is because according to (1), $2 q(\widetilde{\omega}, \widetilde{\omega})>q\left(\omega_{d}^{r}(\bar{\gamma}), \bar{\omega}_{f}\right)$. Close to $\bar{\gamma}$, the wage-enhancing effect associated with a marginal wage increase is of second order, while the employment-reducing effect is of first order.

At $\gamma=\widetilde{\omega}$, where the union rent under a wage moderation strategy becomes zero, the union rent is strictly higher in the regime with offshoring because all laid-off workers receive $\widetilde{\omega}$ and a few receive $\omega_{d}^{r}>\widetilde{\omega}$ in such a case, whereas all trade union members receive $\widetilde{\omega}$ in the symmetric case without offshoring. As a result, there is a critical level $\bar{\gamma}<\gamma^{*}<\widetilde{\omega}$ at which the union becomes indifferent to following a low-wage/high-employment strategy or a high-wage/low-employment strategy.

The lower part of figure 2 shows the corresponding union rents as a function of the outside option $\gamma$. First, according to (16), it is clear that the union rent $\theta_{n}$ under constrained bargaining decreases linearly with $\gamma$, whereas the union rent arising from unconstrained bargaining in the regime without offshoring decreases and is convex in $\gamma$ (see appendix A.3). Furthermore, note that by definition, $\theta_{n}^{u}(\underline{\gamma})=\theta_{n}^{c}(\underline{\gamma})$ at $\gamma=\underline{\gamma}$ because $\omega^{n}(\delta, \underline{\gamma})=\widetilde{\omega}\left(\bar{\omega}_{f}, K\right)$ (see (15)). For values of $\gamma$ above $\underline{\gamma}$, the rent $\theta_{n}^{c}$ is captured by the straight line, whereas $\theta_{n}^{u}$ is shown by the dotted curve. The latter is only meaningful in the absence of firm mobility. Since the union only extracts a rent as long as the negotiated wage exceeds the outside option, we can state that $\theta_{n}^{c}(\gamma)=0 \Leftrightarrow \gamma=\widetilde{\omega}$ and $\theta_{n}^{u}(\gamma)=0 \Leftrightarrow \gamma=\alpha>\widetilde{\omega}$.

The union rent in the offshoring regime, $\theta_{r}(\gamma)$, is obtained by substituting (13) into (12). It is also a monotonically decreasing and convex function of $\gamma$ (see appendix A.4). In section 4.2 , we showed that for any given level of $\gamma$, both the negotiated wage and domestic industry employment are unambiguously higher when both firms produce domestically and the union is unconstrained from charging a wage above $\widetilde{\omega}$. Hence, for $0 \leq \gamma \leq \underline{\gamma}$, we know that $\theta_{n}(\gamma)>\theta_{r}(\gamma)$. Clearly, for $\gamma>\underline{\gamma}$ the union rents $\theta_{n}^{c}$ and $\theta_{r}$ must intersect, since $\theta_{r}(\gamma)=0 \Leftrightarrow \gamma=\gamma_{\max }\left(\bar{\omega}_{f}, K\right)$ while $\theta_{n}^{c}=0 \Leftrightarrow \gamma=\widetilde{\omega}\left(\bar{\omega}_{f}, K\right)$. Since $\bar{\gamma}<\widetilde{\omega}$ implies $K<\bar{K}\left(\bar{\omega}_{f}\right):=\frac{2\left(\alpha-\bar{\omega}_{f}\right)^{2}}{9 \beta}$, we can state that $\gamma_{\max }\left(\bar{\omega}_{f}, K\right)>\widetilde{\omega}\left(\bar{\omega}_{f}, K\right)$.

Summing up, we can define the equilibrium domestic wage rate depending on the outside option as 


$$
\omega^{*}= \begin{cases}\omega^{n}(\delta, \gamma) & \text { if } 0 \leq \gamma<\underline{\gamma}, \\ \widetilde{\omega}\left(\bar{\omega}_{f}, K\right) & \text { if } \underline{\gamma} \leq \gamma<\gamma^{*}, \\ \omega_{d}^{r}\left(\delta, \gamma, \bar{\omega}_{f}\right) & \text { if } \gamma^{*} \leq \gamma<\gamma_{\max } .\end{cases}
$$

This is illustrated by the bold line in the upper part of figure 2. Our findings so far can be summarised by the following proposition:

Proposition 1: The labour union's attitude towards offshoring depends on the income workers can expect to obtain outside the industry. Specifically, if (i) $0 \leq \gamma<\underline{\gamma}$, the negotiated wage, $\omega^{n}(\delta, \gamma)$, is below the critical level that induces offshoring; (ii) $\underline{\gamma} \leq \gamma<\gamma^{*}$, the union adopts a wage moderation strategy by setting the indifference wage $\widetilde{\omega}\left(\bar{\omega}_{f}, K\right)$ in such a way as to discourage the MNE from offshoring; (iii) $\gamma^{*} \leq \gamma<\gamma_{\max }$, the union is not willing to moderate wages and adopts a high-wage/lowemployment strategy by demanding $\omega_{d}^{r}\left(\delta, \gamma, \bar{\omega}_{f}\right)>\widetilde{\omega}\left(\bar{\omega}_{f}, K\right)$ and inducing offshoring.

\section{Comparative statics: The impact of globalisation}

Globalisation is generally associated with lower costs of mobility and a more intense competitive environment worldwide. In this sense, our model allows us to explore the impact of deeper international integration on the relationship between the workers' expected outside income and the equilibrium wage. The $\widetilde{\omega}$-line in the upper part of figure 2 indicates the indifference wage for the MNE as a function of the foreign wage rate and the fixed relocation costs. As we have seen, lower values of $\mathrm{K}$ increase the attractiveness of the foreign country. As illustrated in figure 3 , the $\widetilde{\omega}$-line shifts downwards when K falls, so that $\underline{\gamma}$ and $\bar{\gamma}$ shift to the left in parallel to $\underline{\gamma}^{\prime}$ and $\bar{\gamma}^{\prime}$, respectively. Hence, the lowest level of the outside option that forces the trade union to moderate its wage demands decreases when $\mathrm{K}$ falls. Regarding the critical level at which the union will switch from a wage moderation strategy to a high-wage/low-employment strategy, it also falls unambiguously from $\gamma^{*}$ to $\gamma^{* \prime}$. In order to see this, note that the kink in the $\theta_{n}$-curve in the lower part of figure 3 moves to the left along the curve, as the straight line representing the union rent under constrained bargaining rotates clockwise, connecting the points $\theta_{n}\left(\underline{\gamma}^{\prime}\right)$ and $\theta_{n}\left(\widetilde{\omega}^{\prime}\right)$. Hence, the no-relocation rent now lies below its previous position. Since the rent in the relocation case does not change, 


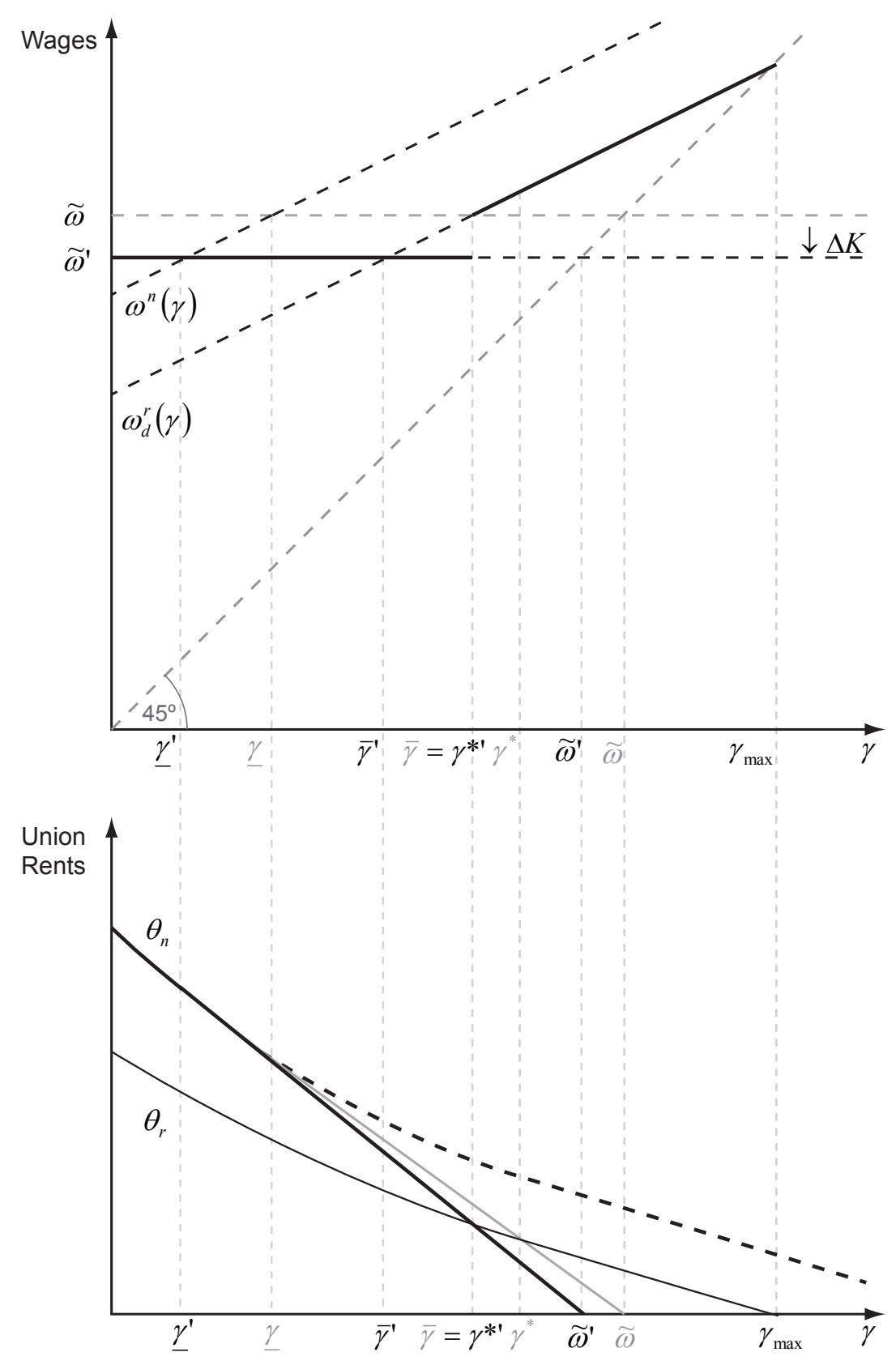

Figure 3: The effects of lower sunk firm relocation costs.

the intersection of the two curves $\theta_{n}^{c}$ and $\theta_{r}$ is now at $\gamma^{* \prime}<\gamma^{*}$. Formally, one can show that the union rent in the constrained bargaining regime is an increasing function of the indifference wage (see appendix A.3). Consequently, for a given $\gamma, \theta_{n}^{c}$ decreases as $K$ - and therefore $\widetilde{\omega}$ - decrease. Moreover, $\theta_{n}^{c}$ is generally steeper than $\theta_{n}^{u}$ when $\gamma=\underline{\gamma}$ (see appendix A.3).

Intuitively, $\gamma^{*}$ falls because lower mobility costs translate into a lower indifference wage and 
therefore $\theta_{n}^{c}(\gamma)$ decreases, whereas $\theta_{r}(\gamma)$ remains unaffected as it captures the (anticipated) union rent when the mobile firm has already relocated. Since the rent surplus depends on the difference between the negotiated wage and the reservation wage $\gamma$, a drop in $K$ leads to a fall in the threshold $\gamma^{*}$ at which the union is indifferent to offshoring versus domestic production.

Thus, the model supports the well-established result that the option of shifting production abroad restrains unions and lowers wages (e.g. Mezzetti and Dinopoulos, 1991; Zhao, 1995; Koskela and Schöb, 2009). However, our model relativises this result in that it predicts that there is an interval $\left[\gamma^{* \prime} ; \gamma^{*}\right]$ where increased globalisation induces the union to switch from a low-wage/high-employment strategy to a high-wage/low employment strategy and thus trigger offshoring.

Proposition 2: Deeper economic integration in the form of lower mobility costs has the following effects:

(i) The indifference wage falls, i.e. $\frac{\partial \widetilde{\omega}}{\partial K}>0$;

(ii) The union is forced to moderate its wage demands at lower levels of $\gamma$, i.e. $\frac{\partial \gamma}{\partial \bar{K}}>0$;

(iii) The threshold value for the workers' outside option at which the union is indifferent regarding the mobile firm's location falls, i.e. $\frac{\partial \gamma^{*}}{\partial K}>0$. Hence, there exists an interval $\left[\gamma^{* \prime} ; \gamma^{*}\right]$ where the trade union changes from a low-wage/high-employment strategy to a highwage/low-employment strategy.

Proposition 2 states that there is an interval where it is optimal for the trade union to change its strategy when relocation $\operatorname{costs} K$ decrease. In the close neighbourhood to the left of $\gamma^{*}$, a fall in $K$ unambiguously goes hand in hand with higher equilibrium domestic wages at the cost of an increase in the relocation-induced displacement of workers. More precisely, whether or not offshoring leads to an increase in the domestic wage rate depends on both the level of $\gamma$ and the magnitude of the cost reduction, $\Delta K$. Consider the case in figure 3 , where $K$ falls by such an amount, $(\Delta K)^{*}$, such that the intersection of the shifted $\theta_{n}^{c}$ and $\theta_{r}$-curves occurs at the initial $\bar{\gamma}$, where $\widetilde{\omega}=\omega_{d}^{r}$. Then, for $\gamma \in\left[\underline{\gamma}^{\prime}, \bar{\gamma}\right]$ the union continues to moderate wages and accept the lower indifference wage $\widetilde{\omega}^{\prime}$. At $\gamma=\bar{\gamma}$, however, a marginal increase in $\gamma$ induces the union to switch away from a wage-moderation strategy. In this case, the wage negotiated with the immobile firm unambiguously exceeds the initial 
indifference wage, $\widetilde{\omega}$. However, if the size of the cost reduction exceeds $(\Delta K)^{*}$, the indifference wage falls further so that $\gamma^{* \prime}<\bar{\gamma}$. Then, in the area just to the left of the initial $\bar{\gamma}$, it is optimal for the trade union to change to the high-wage strategy even if the negotiated wage falls short of the initial indifference wage, $\widetilde{\omega}$. This can be summarised as follows:

Proposition 3: If increased globalisation due to falling $K$ induces the trade union to give up part of the workforce, the resulting negotiated wage depends on both the initial outside option and the extent to which $K$ is reduced. Specifically, let $(\Delta K)^{*}$ be the magnitude of the cost reduction so that when $\gamma=\bar{\gamma}$ workers are indifferent to the mobile firm's location, i.e. $\theta_{r}(\bar{\gamma})=\theta_{n}^{c}(\bar{\gamma})$. Then,

(i) if $\Delta K \leq(\Delta K)^{*}, \gamma^{* \prime} \in\left(\bar{\gamma}, \gamma^{*}\right)$ and for $\gamma \geq \gamma^{* \prime}$ we obtain $\omega_{d}^{r \prime}>\widetilde{\omega}$;

(ii) if $\Delta K>(\Delta K)^{*}, \gamma^{* \prime} \in\left(\bar{\gamma}^{\prime}, \bar{\gamma}\right)$

and for $\gamma \in\left(\gamma^{* \prime}, \bar{\gamma}\right)$ we obtain $\omega_{d}^{r \prime}<\widetilde{\omega}$

whereas for $\gamma>\bar{\gamma}$ we obtain $\omega_{d}^{r \prime}>\widetilde{\omega}$.

We can also consider the effects of fiercer global competition in the form of lower variable foreign labour costs, $\bar{\omega}_{f}$. In that case, the potential profits obtainable abroad increase so that the $\widetilde{\omega}$-line shifts downwards. Additionally, provided that the mobile firm produces abroad, the effect of a lower foreign wage is to reduce the immobile firm's profit, which dampens the domestic wage rate (see equation (13)). For every level of $\gamma$, therefore, the $\omega_{d}^{r}$-line also shifts downwards. The overall effect is that both $\underline{\gamma}$ and $\bar{\gamma}$ shift to the left, ${ }^{13}$ but the $[\underline{\gamma}, \bar{\gamma}]$-interval widens. Furthermore, since both the $\theta_{n}^{c}(\gamma)$-curve and the $\theta_{r}(\gamma)$-curve in the lower part of figure 3 shift downwards in this case, the overall effect on $\gamma^{*}$ is ambiguous because of the countervailing effect created by fiercer oligopolistic competition. In other words, a high-wage strategy involving offshoring and tough import competition, may be less desirable than a wage moderation strategy. The interval in which the trade union changes strategies becomes smaller, and the resulting wage will be lower.

\section{General equilibrium and the welfare state}

The government uses a labour tax to finance a public good $G$ (which is assumed to enter all individuals' utilities in an additively separable manner) and unemployment benefit

\footnotetext{
${ }^{13}$ Note that we have $\frac{\partial \bar{\gamma}}{\partial \bar{\omega}_{f}}>0$
} 
payments, b. We have $\mathrm{N}$ sectors, so the budget constraint is given by

$$
\tau \sum_{N} \omega_{N} Q_{N}=G+\left(N-\sum_{N} Q_{N}\right)(1-\tau) b
$$

where

$$
Q_{N}= \begin{cases}2 q_{N}^{n} & \text { if the mobile firm does not relocate } \\ q_{N d}^{r} & \text { otherwise }\end{cases}
$$

denotes domestic employment in sector $N$ and $\omega_{N}$ the negotiated wage in that sector. If we define $L=\sum_{N} Q_{N}$ as the aggregate employment level, noting that the total labour supply is $N$, the unemployment rate is given by $u=N^{-1}(N-L)$.

The general equilibrium analysis takes the interaction between the different sectors into account. These interactions crucially depend on the assumption we make about the rest of the economy. One possibility is to assume that the rest of the economy is characterised by a competitive labour market. In this case, the outside income would correspond to $\gamma=\bar{\omega}=\omega^{c}$ where $\omega^{c}$ refers to the gross wage rate in a competitive labour market. Alternatively, we can assume that the other sectors are also unionised, in which case there is unemployment in equilibrium. The extent to which unemployment affects the outside option depends on whether laid-off workers in the industry in question are able to find employment elsewhere. An empirical investigation by Burda and Mertens (2001) indicates that around $80 \%$ of all workers in Germany who had been involuntarily dismissed from their jobs in 1986 had socially insured employment even 4 years after displacement. Egger et al. (2007) examine the consequences of relocating production for workers using individual-level panel data from Austria. Their main finding is that outsourcing reduces the flow of worker to the sectors in which the economy has a comparative disadvantage, which is not offset by a proportionate inflow of workers to the sectors with a comparative advantage. This suggests that outsourcing leads to an increase in net unemployment. Such a relationship is also supported by Kletzer (2000) for the US. This points to the importance of the country's unemployment rate in determining the extent to which offshoring is prone to generating long-term unemployment among workers who lose their jobs due to such shifts in production. We therefore adopt the standard assumption that the outside option is given by (4), i.e. $\gamma=(1-u) \bar{\omega}+u b$. Furthermore, we consider a country in which all sectors are exposed to offshoring. In order 
to determine the general equilibrium, we assume that all sectors are symmetric. This implies that all sector wages are the same in equilibrium, so that $\omega_{N}=\bar{\omega} \equiv \omega \forall N$. We proceed by characterising the general equilibrium for the three potential wage regimes identified in proposition 1, starting with the autarky case.

1. $\gamma<\underline{\gamma}$

When offshoring is too expensive to be a credible threat in wage bargaining, the negotiations in all sectors yield the wage rate (9) and subsequently sector employment (10). Additionally, we have to consider the outside option, $\gamma$, which in equilibrium is determined by the equilibrium wage rates and employment. We thus have three equations that must hold in equilibrium:

$$
\begin{array}{ll}
F^{1}: & \omega-\left(1-\frac{\delta}{2}\right) \gamma-\frac{\delta}{2} \alpha=0 \\
F^{2}: & \gamma-(1-u) \omega-u b=\gamma-\left(1-\frac{N-L}{N}\right) \omega-\frac{N-L}{N} b=0 \\
F^{3}: & L+N \frac{\omega}{3 \beta}-N \frac{\alpha}{3 \beta}=0
\end{array}
$$

Furthermore, the balanced budget constraint (17) must be met. As we are interested in how a more generous welfare system affects the labour market, we analyse how an increase in $b$, indicating a more redistributive system, affects the wage rate and employment. Using total differentials $F_{\omega}^{i}+F_{\gamma}^{i}+F_{L}^{i}=-F_{b}^{i}, i=1,2,3$ and applying Cramer's rule (see appendix A.5 for details), we obtain the following results:

$$
\begin{aligned}
& \frac{d \omega}{d b}=D^{-1} u\left(1-\frac{\delta}{2}\right)>0 \\
& \frac{d \gamma}{d b}=D^{-1} u>0 \\
& \frac{d L}{d b}=-D^{-1}\left(1-\frac{\delta}{2}\right)\left(u N \frac{1}{3 \beta}\right)<0
\end{aligned}
$$

where

$$
D=1+\left(1-\frac{\delta}{2}\right)\left(\frac{\omega-b}{3 \beta}-(1-u)\right)=1-\underbrace{\left(1-\frac{\delta}{2}\right)(1-u)}_{<1}+\left(1-\frac{\delta}{2}\right)\left(\frac{\omega-b}{3 \beta}\right)>0
$$

An increase in unemployment benefit payments will increase gross wages, thus reducing ag- 
gregate employment. Hence, as long as offshoring is not an alternative for the mobile firm, the model confirms standard results from the literature which show that there is a tradeoff between a more redistributive system and employment (e.g. Nickell et al., 2005).

\section{2. $\underline{\gamma} \leq \gamma<\gamma^{*}$}

In this interval, the trade union will accept the indifference wage which ensures that the mobile firm does not relocate abroad. The outside option is then given by $\gamma=(1-u) \widetilde{\omega}+u b$ but it is irrelevant in wage negotiations. Employment is given by (1). As long as an increase in the outside option does not increase wages, it will have no effect on employment. Thus, for $\underline{\gamma} \leq \gamma<\gamma^{*}$ we have

$$
\frac{d \omega}{d b}=\frac{d L}{d b}=0
$$

and

$$
\frac{d \gamma}{d b}=u
$$

This result is in line with our finding in section 4 . When offshoring becomes attractive for the mobile firm, the best response on the trade union's part is to moderate wages in such a way that the mobile firm is kept in the home country. This fixes the wages and makes them independent of the generosity of the welfare system. Furthermore, the financing of more redistribution does not affect the gross wages as the entire incidence falls on net wages. Even though the prospect of becoming unemployed becomes less distressful, overal domestic employment is not affected. In effect, notwithstanding the presence of trade unions, redistribution becomes costless for the government because the wage is determined by forces totally unrelated to the workers' bargaining power. In fact, the major concern of workers is for their labour costs to remain sufficiently attractive compared to mobile firms' outside opportunities, which are basically affected by $K$ and $\bar{\omega}_{f}$. If the government prefers more redistribution, it would be optimal from the government's perspective to choose a replacement ratio that just ensures $\gamma^{*}$. This result is in sharp contrast to the statement that globalisation leads to a race to the bottom among welfare states. An increase in $b$ raises the outside option but it has no repercussions for unemployment.

3. $\gamma=\gamma^{*}$

If we raise $b$ at the critical level $\gamma=\gamma^{*}$, the outside option improves, ceteris paribus, 
$\partial \gamma^{*} / \partial b=u$. It becomes attractive for the trade unions to raise the wage above the indifference level even if this compels the mobile firm to relocate abroad. If a first firm relocates, however, the outside option $\gamma$ falls until it reaches $\gamma^{*}$ again, in which case there is no incentive for further unions to switch to the high-wage/low-employment strategy.

In order to show that the relocation of one firm from sector $x$ dampens the outside option, we rewrite $\gamma$ as

$$
\gamma=\frac{\sum_{z \neq x} Q_{z}\left(\omega_{z}-b\right)+q_{x}\left(\omega_{x}-b\right)}{N}+b .
$$

Before offshoring, we had $\left[q_{x}\left(\omega_{x}-b\right)\right]=2 q^{n}(\widetilde{\omega})(\widetilde{\omega}-b)$ in sector $x$. After offshoring, we have $q_{x}\left(\omega_{x}-b\right)=q_{d}^{r}\left(\omega_{d}^{r}-b\right)$. Thus,

$$
\Delta \gamma=\frac{1}{N}\left[q_{d}^{r}\left(\omega_{d}^{r}-b\right)-2 q^{n}(\widetilde{\omega})(\widetilde{\omega}-b)\right]=\frac{1}{N}\left[q_{d}^{r} \omega_{d}^{r}-2 q^{n}(\widetilde{\omega}) \widetilde{\omega}+b\left(2 q^{n}(\widetilde{\omega})-q_{d}^{r}\right)\right] .
$$

At $\gamma^{*}$ we know that for each sector $\theta_{n}=\theta_{r}$, which according to (16) and (12) implies that $\left(\widetilde{\omega}-\gamma^{*}\right) 2 q^{n}(\widetilde{\omega})=\left(\omega_{d}^{r}-\gamma^{*}\right) q_{d}^{r}$ and thus $q_{d}^{r} \omega_{d}^{r}-2 q^{n}(\widetilde{\omega}) \widetilde{\omega}=-\gamma^{*}\left(2 q^{n}(\widetilde{\omega})-q_{d}^{r}\right)$. Substituting into (19) yields

$$
\Delta \gamma=\frac{1}{N}\left[-\gamma^{*}\left(2 q^{n}(\widetilde{\omega})-q_{d}^{r}\right)+b\left(2 q^{n}(\widetilde{\omega})-q_{d}^{r}\right)\right]=-\frac{2 q^{n}(\widetilde{\omega})-q_{d}^{r}}{N}\left(b-\gamma^{*}\right)<0
$$

since $\omega>b$ implies that $\gamma^{*}>b$ for any $u<1$. Hence, the shift of one sector to a highwage/low-employment strategy that induces offshoring will lower the equilibrium outside option. Therefore, as long as not all mobile firms have relocated, higher unemployment benefit payments will trigger partial offshoring. For this case, our analysis thus shows that a more generous welfare state creates adverse effects in the form of a lower domestic level of employment. Beyond the marginal increase in unemployment caused by higher unemployment benefits, also observed in the absence of offshoring, redistribution now leads to outward firm relocations. The larger the sectors, the stronger the implications for unemployment. Note that in this case there are two wages in equilibrium. While workers in those sectors where the trade union still moderates wages only receive the indifference wage $\widetilde{\omega}$, the high-wage/low-employment sectors pay a higher wage $\omega_{d}^{r}\left(\gamma^{*}\right)$.

4. $\gamma^{*}<\gamma$

If the outside option is sufficiently high, all mobile firms eventually relocate and the com- 
parative statics resembles those in case 1, albeit at lower employment levels. In other words, we observe increasing wages and falling employment when unemployment benefit payments are raised.

Figure 4 summarises the general equilibrium effects. Below $\underline{\gamma}$, we can observe a case of

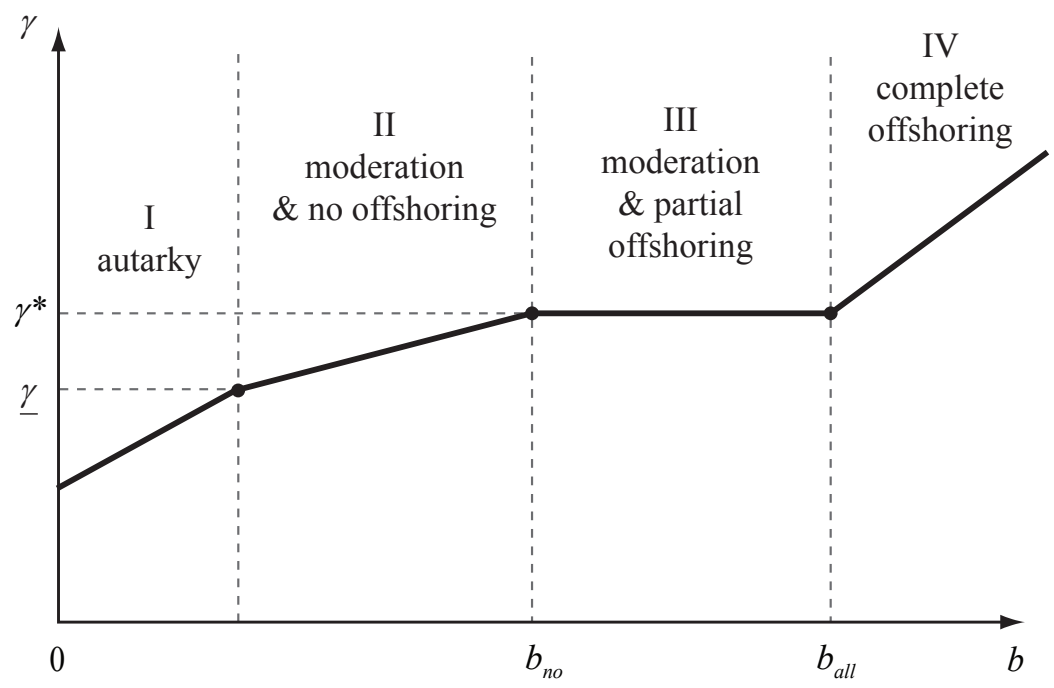

Figure 4: Redistribution.

autarky. Redistribution is costly as it increases wage demands and thus lowers employment. Above $\underline{\gamma}$, offshoring becomes attractive for mobile firms if trade unions demand sufficiently high wages. This leads to wage moderation, which in turn enables the government to redistribute income from workers to unemployed people at no cost. Although the outside option increases linearly along with $b$, figure 2 already showed that this has no repercussions with regard to allocation. This is possible until a critical value for the unemployment benefit payment $b_{n o}$ is reached. Beyond $b_{n o}$, a higher $b$ prompts some firms to move offshore, which in turn brings the outside option back down to $\gamma^{*}$. Thus, a more generous unemployment benefit system has no effect on the outside option until the last sector has lost its mobile firm. This is the case at $b_{\text {all }}$, beyond which no sector is threatened by any further offshoring. These findings can be summarised as follows:

Proposition 4: For any given degree of globalisation, a more generous unemployment benefit system in the form of higher unemployment benefit payments $b$

(i) leads to higher domestic wages and lower employment without triggering offshoring if 
$\gamma<\underline{\gamma}$

(ii) does not affect domestic wages and employment and does not trigger offshoring if $\underline{\gamma} \leq$ $\gamma<\gamma^{*}$

(iii) causes offshoring and reduces employment if $\gamma=\gamma^{*}$. Domestic firms in sectors with wage moderation continue to pay the indifference wage $\widetilde{\omega}$, while firms in the high-wage/lowemployment sectors pay the higher wage $\omega_{d}^{r}\left(\gamma^{*}\right)$;

(iv) induces all remaining mobile firms across all sectors to relocate abroad and increases domestic unemployment further, if $\gamma>\gamma^{*}$, where the wage rate for employed domestic workers amounts to $\omega_{d}^{r}(\gamma)>\omega_{d}^{r}\left(\gamma^{*}\right)$.

\section{Conclusion}

This paper has explored the implications of welfare policies for domestic employment and wages in industries which are unionised and potentially affected by offshoring. In this context, we have focused on the extent to which policies regarding unemployment insurance affect the interaction between labour unions and oligopolistic firms, some of which are internationally mobile. More specifically, we were interested in the extent to which a generous unemployment insurance system can be held responsible for the relocation-induced loss of jobs, when the various actors' incentives are taken into account.

A typical result in standard trade union models that ignore offshoring is that a more generous welfare system leads to higher gross wages and a lower level of aggregate employment. This is confirmed in our model for the benchmark case where offshoring is too expensive to pose a threat in wage negotiations. If offshoring is a viable option and the workers' fallback option is sufficiently high, few domestic workers would benefit from higher wages, while many would lose their jobs. Thus, trade unions are forced to moderate their wage demands by setting a wage that leaves internationally mobile firms just indifferent to domestic production versus offshoring. Such a wage is actually independent of the generosity of the welfare system. As long as welfare arrangements are not too generous, the financing of additional redistribution does not affect these gross wages so that the entire incidence falls on net wages. Hence, redistribution from employed to unemployed individuals is non-distortive from the government's perspective. A government with a high preference for redistribution would therefore optimally choose as high a level of unemployment insurance benefits as possible that is still consistent with the union's preference for wage moderation. This prediction only changes if 
the welfare system expands beyond a certain limit. Then some trade unions will opt for a high-wage/low-employment strategy, which leads to offshoring and domestic job losses.

Our finding has interesting policy implications. Even if deeper economic integration dampens the wage rate prevailing under a moderation regime, there is scope for substantial redistribution without the threat of losing production. This runs counter to the widespread view that globalisation leads to a race to the bottom in social policy. In fact, the opposite effect emerges: The threat that some mobile firms might relocate abroad compels trade unions to moderate wages and thus creates more leeway for the government to engage in redistribution policies. Only if the welfare state's engagement in redistribution reaches a critical level that induces some offshoring will increased economic integration work to depress the wage prevailing under a moderation regime and thus render a high-wage/low-employment strategy more attractive. In this regard, our results support the finding in Keuschnigg and Ribi (2009) that, in the presence of mobile production, redistribution might involve a smaller efficiency cost than is commonly perceived. Rather than provoking a race to the bottom, our analysis suggests that offshoring defines an upper limit for the generosity of the welfare state below which, however, redistribution becomes less costly.

\section{A Appendix}

\section{A.1 Derivation of the equilibrium wage rate in the regime without relocation}

Define $A \equiv 2(\omega-\gamma)(1-\tau) q(\omega)$ and $B \equiv 2 \beta q^{2}(\omega)$ so that the Nash bargaining product given by (8) corresponds to $\Omega(\omega)=A^{\delta} B^{1-\delta}$. The first-order condition for an interior maximum of (8) over $\omega$ is then given by

$$
\begin{aligned}
\delta A^{\delta-1} 2(1-\tau)\left(q(\omega)+(\omega-\gamma) \frac{\partial q(\omega)}{\partial \omega}\right) B^{1-\delta}+A^{\delta}(1-\delta) B^{-\delta} 4 \beta q(\omega) \frac{\partial q(\omega)}{\partial \omega} & = \\
\frac{\delta}{\omega-\gamma}\left(q(\omega)+(\omega-\gamma) \frac{\partial q(\omega)}{\partial \omega}\right)+2(1-\delta) \frac{\partial q(\omega)}{\partial \omega} & = \\
\delta(\alpha-2 \omega+\gamma)-2(1-\delta)(\omega-\gamma) & = \\
\delta \alpha+(2-\delta) \gamma-2 \omega & =0
\end{aligned}
$$




\section{A.2 Derivation of the equilibrium wage rate in the relocation regime}

Define $C \equiv 2\left(\omega_{d}-\gamma\right)(1-\tau) q_{d}\left(\omega_{d}, \omega_{f}\right)$ and $D \equiv 2 \beta\left[q_{d}\left(\omega_{d}, \omega_{f}\right)\right]^{2}$ so that the Nash bargaining product (11) corresponds to $\Omega_{r}\left(\omega_{d}\right)=C^{\delta} D^{1-\delta}$. The first-order condition with respect to the domestic wage rate is then given by

$$
\begin{array}{r}
\delta C^{\delta-1}(1-\tau)\left(q_{d}\left(\omega_{d}, \omega_{f}\right)+\left(\omega_{d}-\gamma\right) \frac{\partial q_{d}\left(\omega_{d}, \omega_{f}\right)}{\partial \omega_{d}}\right) D^{1-\delta}+ \\
C^{\delta}(1-\delta) D^{-\delta} 2 \beta q_{d}\left(\omega_{d}, \omega_{f}\right) \frac{\partial q_{d}\left(\omega_{d}, \omega_{f}\right)}{\partial \omega_{d}}= \\
\frac{\delta}{\omega_{d}-\gamma}\left(q_{d}\left(\omega_{d}, \omega_{f}\right)+\left(\omega_{d}-\gamma\right) \frac{\partial q_{d}\left(\omega_{d}, \omega_{f}\right)}{\partial \omega_{d}}\right)+2(1-\delta) \frac{\partial q_{d}\left(\omega_{d}, \omega_{f}\right)}{\partial \omega_{d}}
\end{array}
$$

\section{A.3 How the union rent depends on the workers' outside option and the indifference wage when mobile firms do not relocate abroad}

It is easy to show that the union rent under unconstrained bargaining conditions in the regime without offshoring decreases and is convex in $\gamma$ :

$$
\begin{gathered}
\frac{\partial \theta_{n}^{u}}{\partial \gamma}=\left[\left(\frac{\partial \omega^{n}}{\partial \gamma}-1\right) q^{n}(\gamma)+\left[\omega^{n}(\gamma)-\gamma\right] \frac{\partial q^{n}}{\partial \gamma}\right] 2(1-\tau)=-\left[\delta q^{n}(\gamma)+\left[\omega^{n}(\gamma)-\gamma\right] \frac{2-\delta}{3 \beta}\right](1-\tau)<0 \\
\frac{\partial^{2} \theta_{n}^{u}}{\partial \gamma^{2}}=-\left[\delta \frac{\partial q^{n}}{\partial \gamma}+\left(\frac{\partial \omega^{n}}{\partial \gamma}-1\right) \frac{2-\delta}{3 \beta}\right](1-\tau)>0
\end{gathered}
$$

since $\frac{\partial q^{n}}{\partial \gamma}<0$ and $\frac{\partial \omega^{n}}{\partial \gamma}=1-\frac{\delta}{2}<1$.

When the union is constrained in bargaining, its rent is increasing with the indifference wage:

$$
\frac{\partial \theta_{n}^{c}}{\partial \widetilde{\omega}}=2\left[q^{n}(\widetilde{\omega})+\frac{\partial q^{n}}{\partial \widetilde{\omega}}(\widetilde{\omega}-\gamma)\right](1-\tau)>0 \Leftrightarrow q^{n}(\widetilde{\omega})+\frac{\partial q^{n}}{\partial \widetilde{\omega}}(\widetilde{\omega}-\gamma)>0 \Leftrightarrow \alpha-2 \widetilde{\omega}+\gamma>0
$$

Since the left hand side of the latter inequality is increasing with $\gamma$ and since the lowest 
value of $\gamma$ consistent with wage moderation is $\underline{\gamma}$, we substitute $\gamma=\underline{\gamma}$. Using (3) we have

$$
(1-\delta)\left[\alpha-\bar{\omega}_{f}-\frac{9 \beta}{4\left(\alpha-\bar{\omega}_{f}\right)} K\right]>0 \forall K<\bar{K}_{\left(\bar{\omega}_{f}\right)}
$$

Moreover, at $\gamma=\underline{\gamma}$, the union rent is steeper under constrained bargaining. Specifically,

$$
\left|\frac{\partial \theta_{n}^{c}}{\partial \gamma}\right|>\left|\frac{\partial \theta_{n}^{u}}{\partial \gamma}\right|
$$

holds if $2 q^{n}(\widetilde{\omega})>\delta q^{n}(\gamma)+\left(\omega^{n}(\gamma)-\gamma\right) \frac{2-\delta}{3 \beta}$ which when setting $\gamma=\underline{\gamma}$ holds if $\alpha-2 \widetilde{\omega}+\underline{\gamma}>0$. Substituting $\widetilde{\omega}$ and $\underline{\gamma}$ with (3) and (15), respectively, yields $2(1-\delta)(\alpha-\widetilde{\omega})>0 \forall K<$ $\bar{K}\left(\bar{\omega}_{f}\right)$.

\section{A.4 How the union rent in the relocation regime depends on the workers' outside options}

When the mobile firm competes from abroad, the domestic union rent is decreasing and convex in $\gamma$ :

$$
\begin{gathered}
\frac{\partial \theta_{r}}{\partial \gamma}=\left[\left(\frac{\partial \omega_{d}^{r}}{\partial \gamma}-1\right) q_{r}^{r}(\gamma)+\left[\omega_{d}^{r}(\gamma)-\gamma\right] \frac{\partial q_{d}^{r}}{\partial \gamma}\right](1-\tau)=-\left[\frac{\delta}{2} q_{d}^{r}(\gamma)+\left[\omega_{d}^{r}(\gamma)-\gamma\right] \frac{2-\delta}{3 \beta}\right](1-\tau)<0 \\
\frac{\partial^{2} \theta_{r}}{\partial \gamma^{2}}=-\left[\frac{\delta}{2} \frac{\partial q_{d}^{r}}{\partial \gamma}+\left(\frac{\partial \omega_{d}^{r}}{\partial \gamma}-1\right) \frac{2-\delta}{3 \beta}\right](1-\tau)>0
\end{gathered}
$$

since $\frac{\partial q_{d}^{r}}{\partial \gamma}<0$ and $\frac{\partial \omega_{d}^{r}}{\partial \gamma}=\frac{\partial \omega^{n}}{\partial \gamma}=1-\frac{\delta}{2}<1$.

\section{A.5 Derivation of the determinant}

Taking the derivatives with respect to $\omega, \gamma, L$ and $b$ yields the following system of equations:

$$
\left|\begin{array}{ccc}
F_{\omega}^{1} & F_{\gamma}^{1} & F_{L}^{1} \\
F_{\omega}^{2} & F_{\gamma}^{2} & F_{L}^{2} \\
F_{\omega}^{3} & F_{\gamma}^{3} & F_{L}^{3}
\end{array}\right|=\left|\begin{array}{c}
-F_{b}^{1} \\
-F_{b}^{2} \\
-F_{b}^{3}
\end{array}\right|
$$


The determinant is

$$
|D|=\left|\begin{array}{ccc}
F_{\omega}^{1} & F_{\gamma}^{1} & F_{L}^{1} \\
F_{\omega}^{2} & F_{\gamma}^{2} & F_{L}^{2} \\
F_{\omega}^{3} & F_{\gamma}^{3} & F_{L}^{3}
\end{array}\right|=\left|\begin{array}{ccc}
1 & -\left(1-\frac{\delta}{2}\right) & 0 \\
-(1-u) & 1 & -\frac{1}{N}(\omega-b) \\
N \frac{1}{3 \beta} & 0 & 1
\end{array}\right|
$$

or

$$
D=1-\underbrace{\left(1-\frac{\delta}{2}\right)(1-u)}_{<1}+\left(1-\frac{\delta}{2}\right)\left(\frac{\omega-b}{3 \beta}\right)>0 .
$$

\section{References}

[1] Torben M. Andersen. Wefare Policies, Labour Taxation and International Integration. International Tax and Public Finance, 10(1):43-62, 2003.

[2] Thomas Aronsson and Tomas Sjögren. Efficient taxation, wage bargaining and policy coordination. Journal of Public Economics, 88:2711-2725, 2004.

[3] Ray Barrell and Nigel Pain. An econometric analysis of US foreign direct investment. The Review of Economics and Statistics, pages 200-207, 1996.

[4] Robin Boadway, Katherine Cuff, and Nicolas Marceau. Inter-jurisdictional competition for firms. International Economic Review, 43(3):761-782, 2002.

[5] James A. Brander and Barbara J. Spencer. Unionized oligopoly and international trade policy. Journal of International Economics, 24:217-234, 1988.

[6] Jacques Bughin and Stefano Vannini. Strategic direct investment under unionized oligopoly. International Journal of Industrial Organization, 13:127-145, 1995.

[7] Michael C. Burda and Antje Mertens. Estimating wage losses of displaced workers in Germany. Labour Economics, 8:15-41, 2001.

[8] Rosario Crinò. Offshoring, multinationals and labour market: A review of the empirical literature. Journal of Economic Surveys, 23(2):197-249, 2009.

[9] Francesco Daveri and Guido Tabellini. Unemployment, growth and taxation in industrialised countries. Economic Policy, 15(30):47-104, 2000.

[10] Vincent Delbecque, Isabelle Méjean, and Lise Patureau. Social competition and firms' location choices. Working Papers 2008-12, CEPII research center, July 2008.

[11] Mihir A. Desai, C. Fritz Foley, and James R. Hines. Foreign direct investment in a world of multiple taxes. Journal of Public Economics, 88:2727-2744, 2004.

[12] Gerda Dewit, Holger Görg, and Catia Montagna. Should I stay or should I go? A note on employment protection, domestic anchorage and FDI. Discussion Papers in Economics 145, University of Dundee, 2003.

[13] Carsten Eckel and Hartmut Egger. Wage bargaining and multinational firms. Journal of International Economics, 77:206-214, 2009.

[14] Hartmut Egger and Peter Egger. Outsourcing and skill-specific employment in a small economy. Oxford Economic Papers, 55:625-643, 2003. 
[15] Hartmut Egger and Peter Egger. On the realtionship between international outsourcing and price-cost margins in European industries. Review of Industrial Organization, 25:45-69, 2004.

[16] Peter Egger, Michael Pfaffermayr, and Andrea Weber. Sectoral adjustment of eomployment to shifts in outsourcing and trade: Evidence from a dynamic fixed effects multinomial logit model. Journal of Applied Econometrics, 22:559-580, 2007.

[17] Peter Egger, Michael Pfaffermayr, and Yvonne Wolfmayr-Schnitzer. The international fragmentation of Austrian manufacturing: The effects of outsourcing on productivity and wages. North American Journal of Economics and Finance, 12:257-272, 2001.

[18] Karolina Ekholm and Katariina Hakkala. The Effect of Offshoring on Labour Demand: Evidence from Sweden. CEPR Discussion Paper No. 5648, 2006.

[19] European Commission. Structures of the taxation systems in the European Union: 1995-2004. Directorate-General for Taxation and Customs Union, and Eurostat, 2006.

[20] Martin Falk and Yvonne Wolfmayr. Employment effects of outsourcing to low wage countries. Empirical evidence for EU countries. WIFO Working Paper 262, WIFO, November 2005.

[21] Robert C. Feenstra and Gordon H. Hanson. The impact of outsourcing and hightechnology capital on wages: Estimates for the United States, 1979-1990. The Quarterly Journal of Economics, 114:907-940, 1999.

[22] Laszlo Goerke. The Wedge. IZA Discussion Paper No.71, 1999.

[23] Holger Görg. Fancy a stay at the "Hotel California"? Foreign direct investment, taxation and firing costs. Discussion Paper 665, IZA, 2002.

[24] Holger Görg and Aoife Hanley. Labour demand effects of international outsourcing: Evidence from plant-level data. International Review of Economics and Finance, 14:365$376,2005$.

[25] Jan Hatzius. Domestic jobs and foreign wages. Scandinavian Journal of Economics, 100(4):733-746, 1998.

[26] Jan Hatzius. Foreign direct investment and factor demand elasticities. European Economic Review, 44(1):117-143, 2000.

[27] Andreas Haufler and Ferdinand Mittermaier. Unionisation triggers tax incentives to attract foreign direct investment. CESIFO Working Paper No. 2312, 2008.

[28] Geoffrey A. Jehle and Philip J. Reny. Advanced Microeconomic Theory. Addison Wesley; 2nd edition, 2000.

[29] Isabelle Joumard. Tax Systems in European Union Countries. OECD Working Paper No. 301, 2001.

[30] Christian Keuschnigg and Evelyn Ribi. Outsourcing, unemployment and welfare policy. Journal of International Economics, 78:168-176, 2009.

[31] Erkki Koskela and Panu Poutvaara. Is there scope for gains from revenue-neutral labor tax reforms with flexible outsourcing? Discussion Paper 3984, IZA, 2009.

[32] Erkki Koskela and Ronnie Schöb. Optimal factor income taxation in the presence of unemployment. Journal of Public Economic Theory, 4:387-404, 2002. 
[33] Erkki Koskela and Ronnie Schöb. Outsourcing of unionized firms and the impact of labor market policy reforms. forthcoming in the Review of International Economics, 2009.

[34] Dermot Leahy and Catia Montagna. Unionisation and FDI: Challenging conventional wisdom? The Economic Journal, 110:80-92, 2000.

[35] Ben Lockwood. Tax Incidence, Market Power, and Bargaining Structure. Oxford Economic Papers, 42:187-209, 1990.

[36] Kjell Erik Lommerud, Frode Meland, and Lars Søgard. Unionised oligopoly, trade liberalisation and location choice. The Economic Journal, 113:782-800, 2003.

[37] Claudio Mezzetti and Elias Dinopoulos. Domestic unionization and import competition. Journal of International Economics, 31:79-100, 1991.

[38] Jakob Roland Munch. The location of firms in unionized countries. Scandinavian Journal of Economics, 105(1):49-71, 2003.

[39] Robin Naylor and Michele Santoni. International trade and economic integration when labour markets are generally unionized. European Economic Review, 42:1251-1267, 1998.

[40] Stephen Nickell, Luca Nunziata, and Wolfgang Ochel. Unemployment in the OECD since the 1960s. What do we know? The Economic Journal, 115:1-27, 2005.

[41] Steve Nickell. Employment and Taxes. CESifo Working Paper No. 1109, 2003.

[42] OECD. The OECD Jobs Study. 1994.

[43] OECD. Employment Outlook: Chapter 3. 2004.

[44] Enrico Pennings and Leo Sleuwaegen. International relocation: firm and industry determinants. Economics Letters, 67:179-186, 2000.

[45] Enrico Pennings and Leo Sleuwaegen. International relocation of production: Where do firms go? Scottish Journal of Political Economy, 53(4):430-446, 2006.

[46] Silvia Rocha-Akis. Essays on strategic fiscal policy in the presence of internationally mobile firms. Dissertation thesis, Vienna University of Economics and Business, 2007.

[47] Jan Rose Skaksen. International outsourcing when labour markets are unionized. Canadian Journal of Economics, 37(1):78-94, 2004.

[48] Mette Rose Skaksen. Should governments subsidise inward foreign direct investment? Scandinavian Journal of Economics, 107(1):123-140, 2005.

[49] Mette Yde Skaksen and Jan Rose Sørensen. Should trade unions appreciate foreign direct investment? Journal of International Economics, 55:379-390, 2001.

[50] Laixun Zhao. Cross-hauling direct foreign investment and unionized oligopoly. European Economic Review, 39:1237-1253, 1995.

[51] Laixun Zhao. The impact of foreign direct investment on wages and employment. Oxford Economic Papers, 50:284-301, 1998. 


\section{Diskussionsbeiträge \\ des Fachbereichs Wirtschaftswissenschaft der Freien Universität Berlin}

2009

2009/1 ENGLER, Philipp

Global Rebalancing in a Three-Country Model

Volkswirtschaftliche Reihe

2009/2 MUCHLINSKI, Elke

Is there a need for a coded language in central banking?

Volkswirtschaftliche Reihe

2009/3 EICHFELDER, Sebastian

Tax compliance costs

Volkswirtschaftliche Reihe

2009/4 SALIM, Claudia

Optional linear input prices in vertical relations

Volkswirtschaftliche Reihe

2009/5 BUSCH, Ulrike / Dieter NAUTZ

Controllability and Persistance of Money Market Rates along the Yield Curve Volkswirtschaftliche Reihe

2009/6 BÖNKE, Timm / Carsten SCHRÖDER

The German spatial poverty divide

Volkswirtschaftliche Reihe

2009/7 BESTER, Helmut

Investments and the Holdup Problem in a Matching Market

Economics

2009/8 MELLER, Barbara / Dieter NAUTZ

The Impact of the European Monetary Union on Inflation Persistence in the Euro Area Economics

2009/9 KREMER, Stephanie / Alexander BICK / Dieter NAUTZ

Inflation and Growth

Economics

2009/10 SCHÖB, Ronnie

Climate Policy

Economics

2009/11 KEREKES, Monika

Growth Miracles and Failures in a Markov Switching Classification Model of Growth Economics

2009/12 KNABE, Andreas / Steffen RÄTZEL

Income, happiness, and the disutility of labor

Economics

2009/13 KNABE, Andreas / Steffen RÄTZEL / Ronnie SCHÖB / Joachim WEIMANN

Dissatisfied with life, but having a good day

Economics 
2009/14 ROCHA-AKIS, Silvia / Ronnie SCHÖB

Welfare policy in the presence of unionised labour and internationally mobile firms Economics 